\title{
AN EMPIRICAL ANALYSIS ON THE OPERATIONAL PROFILE OF LNG CARRIERS WITH STEAM Propulsion Plants
}

Carlos González Gutiérrez ${ }^{\mathrm{a}, 1}$, Santiago Suárez de la Fuente ${ }^{\mathrm{b}}$, Jean-Marc Bonello ${ }^{\mathrm{b}}$ and Richard Bucknall $^{\mathrm{c}}$

${ }^{a}$ Department of Science and Navigation techniques and Shipbuilding, $R+D$ group of Ocean and coastal planning and management, University of Cantabria, Gamazo 1, 39004, Santander, Spain

${ }^{b}$ University College London, Energy Institute, Central House, 14 Upper Woburn Place, London, WC1H 0NN, United Kingdom

${ }^{c}$ University College London, Department of Mechanical Engineering, Roberts Building, Torrington Place, London, WC1E 7JE, United Kingdom

Liquefied Natural Gas (LNG) offers negligible $\mathrm{NO}_{x}$ and $\mathrm{SO}_{\mathrm{x}}$ emissions and reductions in $\mathrm{CO}_{2}$ over other liquid hydrocarbons. LNG is a significant player in the global energy mix, with a projection of $40 \%$ increase in demand for the next decades. It is anticipated that the expected demand rise will cause the fleet of LNG carriers (LNGC) to expand.

This work concentrates on steam-powered LNGC, which accounted for $47 \%$ of the LNGC fleet in 2018. This performs an empirical analysis of Continuous Monitoring data that provide high levels of accuracy and transparency. The analysis is done on data collected from 40 LNGCs over a year to estimate the fleet's operational profile, fuel mix and energy performance.

The findings of this work are relevant for bottom-up analysis and simulation models that depend on technical assumptions, but also for emission studies such as the upcoming $4^{\text {th }}$ International Maritime Organization Greenhouse Gases study.

\section{KEY WORDS}

1. LNG. 2. Energy Efficiency. 3. $\mathrm{CO}_{2}$ emissions. 4. Operational Profiles.

1. INTRODUCTION. Liquefied Natural Gas (LNG) is currently a favoured energy choice by many industries owing to LNG not only producing negligible $\mathrm{NO}_{\mathrm{x}}$ and $\mathrm{SO}_{\mathrm{x}}$ emissions but also offers a reduction in $\mathrm{CO}_{2}$ emissions of around $20 \%$ when compared to residual fuel oil (Calderón et al., 2016). These characteristics make LNG a significant player in the global energy mix (Aguilera, 2014; Economides and Wood, 2009) with LNG demand forecasts projecting an estimated a $40 \%$ increase in the next 20 years (IEA/OECD, 2018). At the same time, global LNG trade has been steadily increasing, with 2017 seeing a 12\% year-on-year growth in trading (International Gas Union, 2018). This has been driven largely by environmental issues; low production cost for LNG; and addition of emerging markets (Varahrami and Haghighat, 2018).

Based on the growth forecast for the global natural gas trade, it is expected that the LNG Carrier (LNGC) fleet will grow significantly in the coming decades (International Energy Agency, 2018; Shaton et al., 2019). This will make the LNGC fleet a significant and relevant segment of maritime transport (UNCTAD, 2018). As of the end of 2018, the LNGC fleet consisted of 525 ships with a projected order book of 128 newbuilds from January 2020 (Information Handling Services Markit, 2020; International Gas Union, 2019). The LNGC fleet is unique in having a diversity of propulsion systems, ranging from conventional steam turbines that provide propulsive and auxiliary power (accounting for 47\% of the LNGC fleet in 2018) to modern two-stroke dual-fuel engines with gas injection (Chang et al., 2008; Ekanem Attah and Bucknall, 2015; Lin et al., 2014).

Liquefied natural gas is transported at $-162^{\circ} \mathrm{C}$ and slightly above atmospheric pressure occupying a volume 600 times smaller than at standard temperature and pressure, resulting in

\footnotetext{
${ }^{1}$ Principal corresponding author. Email address: carlos.gonzalezgu@alumnos.unican.es
} 
a higher energy density. Although LNGC cargo tanks are thermally insulated, a certain amount of heat is transferred to the tank resulting in a continuous evaporation process that increases the tank pressure (Dobrota et al., 2013; Krikkis, 2018). To control the tank pressure the evaporated LNG is vented off, known as boil-off gas (BOG). The BOG can be used as fuel to cover the energy demand or disposed of by producing steam dumped to the main condenser. The steam Turbine Propulsion System (STPS) has historically been the preferred choice for LNGCs due to its simplicity and associated safety in terms of cargo management (Afon and Ervin, 2012; Chang et al., 2008; Ekanem Attah and Bucknall, 2015). The boilers on an STPS can operate simultaneously on Residual Oil (RO) or Distillate Oil (DO); and use BOG fed through centrifugal compressors (Fernández et al., 2017). The steam produced is fed to the main turbine for propulsion; turbo-generators and feed pumps for auxiliary demand; and evaporators for freshwater (Mrzljak et al., 2017).

Studies focusing on operating profiles and energy performance are found to overlook the nuanced differences of the LNGC leading to some inaccuracies. One example is the quantification of ship emissions from Automatic Identification System (AIS) data which is a widely accepted method based on ship activity (Coello et al., 2015; Jalkanen et al., 2016; Kano and Namie, 2014; Moreno-Gutiérrez et al., 2019; Olmer et al., 2017; Smith et al., 2016; Yu et al., 2018). Models based on AIS data approximate ship operational and energy performance using technical assumptions. The variability in the quality of these assumptions produces a diverse set of results from ship performance studies (Merien-Paul et al., 2018; Nunes et al., 2017).

Continuous Monitoring (CM) systems record sensor data and handle the ship performance information coming from different on-board systems. They measure performance parameters to a high level of accuracy transparently. Normally, CM data from a single ship is used as the basis to create predictive performance models that allow for a more efficient ship operation (Coraddu et al., 2017; Gonzalez and Lara Arango, 2019; Petersen et al., 2012; Soner et al., 2018). At the fleet level, the analysis and mining of $\mathrm{CM}$ datasets can extract valuable information and relationships regarding fleet operation and performance (Dalheim and Steen, 2020). Moreover, the high levels of telemetry are helpful towards improving management and deployment of the fleet (Wang et al., 2017). Christensen et al. (2018) characterised operational factors, such as trim and crew, from six containership $\mathrm{CM}$ systems to gain a better understanding of their impact on fuel consumption.

This work aims to provide a deep understanding of how STPS operate. It does so by analysing the main performance characteristics of 40 STPS for over a year. The studied sample consists of about $16.5 \%$ of the fleet as of 2018 (International Gas Union, 2019). This work represents an important empirical contribution to the field of marine engineering as it is, to the best of our knowledge, the only comprehensive work of the steam-powered LNGC fleet. The results obtained from this study will become the empirical basis for future research work in modelling and simulation on LNGC improving the quality of technical assumptions and unlocking future improvement on energy efficiency and emission inventories.

2. METHODOLOGY.

2.1. General overview. The methodology analysed steam-powered LNGC CM data, collected by different on-board sensors (Table 1), coupled with operative assumptions that allow the study of how these ships operate. This work is built on more than 350,000 hourly observations between the end of 2016 and beginning of 2018 from 40 LNGCs.

As depicted in Figure 1, the methodology can be divided as follows: Data Acquisition, Voyage Reports, Pre-Processing, Operational Modelling and Post-Processing.

2.2. Data Acquisition. The Data Acquisition involved the recording and storage of data produced by the sensors in Table 1 . The $\mathrm{CM}$ receives data from the different systems and averages it every 15 seconds applying an exponential moving average between loggings. 
Table 1. Instrumentation used for measuring the inputs on this study.

\begin{tabular}{llc}
\hline Input & Instrumentation & $\begin{array}{c}\text { Associated } \\
\text { Error }\end{array}$ \\
\hline Shaft Power & Torque-meter & $\pm 0.5 \%$ \\
Shaft RPM & Torque-meter & $\pm 0.1 \%$ \\
Fuel consumption & Volumetric flowmeters & $\pm 0.5-1.0 \% \mathrm{a}$ \\
Gas consumption & Coriolis flowmeters & $\pm 0.1-0.2 \% \mathrm{a}^{\mathrm{a}}$ \\
Ship Speed Through Water (STW) & Electromagnetic \& Doppler Log & $\pm 3.0 \% \mathrm{~b}^{\mathrm{b}}$ \\
Ship Speed Over Ground (SOG) & Global Positioning System (GPS) & $\pm 5.0 \% \mathrm{~b}$ \\
Mean Draught & Draught sensors & $\pm 0.1 \mathrm{~m}^{\mathrm{b}}$ \\
Turbo Generators Power output & Kilowatt-meters & $\pm 0.1 \% \mathrm{c}^{\mathrm{c}}$ \\
\hline
\end{tabular}

a:(Hunsucker et al., 2018); ${ }^{\text {b: }}$ (International Organization for Standardization, 2016); ${ }^{\text {c }}$ (Datum

Electronics Limited, 2018)
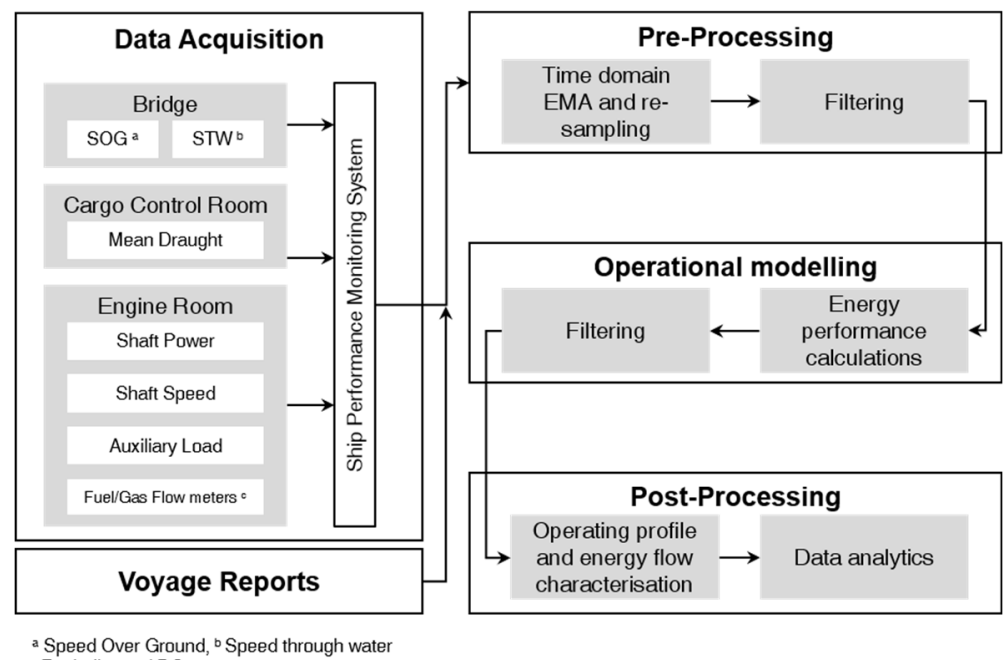

- For boiler and DG sets

Figure 1. Data acquisition and processing flowchart.

2.3. Voyage Reports. It was detected from the Mean Draught data that draught sensors recorded severe fluctuations due to the ship movements (e.g. pitch), type of sensors - normally pressure strain sensors - and their location, seasonal changes and lack of maintenance (Zheng et al., 1999). Voyage reports containing dates and loading condition from the Information Handling Services (IHS) database were merged with the CM to improve voyage definition (Information Handling Services Markit, 2018).

2.4. Pre-processing. During the pre-processing stage, data collected in CM was averaged for one-hour periods (arithmetical average). This generated a total of 357,315 hourly observations per input (e.g. shaft power). The resulting dataset was then cleaned with primary filtering (e.g. abnormal hourly fuel consumptions and speeds above $30.0 \mathrm{kn}$ ), which eliminated $1.60 \%$ of the initial CM dataset with the largest filtering, $10.62 \%$, for abnormal Mean Draught readings. For certain voyages, it was not possible to determine loading conditions or there was very poor AIS coverage which led the authors to eliminate the whole voyage.

\subsection{Operational modelling.}

2.5.1. Power. Steam-powered LNGCs mainly use steam to supply energy to the different consumers on-board such as turbo-generators. Additionally, auxiliary combustion engines, that operate with fuel oil (FO), support the on-board electrical demand. The main boiler's power input $\left(\dot{W}_{i n, b}\right)$ can be provided by the different fuels available on-board. The following equations are used to estimate $\dot{W}_{i n, b}$ :

$$
\begin{gathered}
\dot{W}_{i n, b}=\frac{A+B+C+D}{3600} \\
A=M_{F O} \cdot\left[L H V_{F O}+C P_{F O} \cdot\left(T_{F O}-T A_{i n}\right)\right]
\end{gathered}
$$




$$
\begin{gathered}
B=M_{S A} \cdot\left(h_{S A}-h_{c S}\right) \\
C=M_{a} \cdot\left(h_{a 1}-h_{a 0}\right) \\
M_{a}=15.5 \cdot\left(M_{F O}+M_{B O G}\right) \\
D=M_{B O G} \cdot\left[L H V_{B O G}+C P_{B G} \cdot\left(T_{B G}-T A_{\text {in }}\right)\right]
\end{gathered}
$$

Where $A$ is the energy input by the combustion of the liquid fuel, $B$ is the energy added by the steam for atomising the fuel in the boiler's burners, $C$ is the amount of air needed for the combustion process, and $D$ is the energy added by the BOG combustion. From Equations 2 to 6, $M_{F O}$ is the boiler's hourly liquid FO - RO or/and DO - consumption given by the CM, $L H V_{F O}$ is the fuel's Lower Heating Value (LHV) according to Table 2. The FO specific heat is represented by $C P_{F O}, T_{F O}$ is the fuel temperature at the boiler's burners, $T A_{\text {in }}$ air inlet temperature before entering the boilers, $M_{S A}$ is the assumed design steam flow to the atomisers. The air consumed inside the boilers is represented by $M_{a}, h_{S A}$ is the design steam enthalpy at the atomisers, $h_{c s}$ corresponds with the condensate steam enthalpy, $h_{a 0}$ and $h_{a 1}$ are the air enthalpies before and inside the boilers respectively. The total BOG mass burnt is represented by $M_{B O G}, L H V_{B O G}$ is the LNG's $L H V, C P_{B G}$ is the boiler's exhaust gas specific heat and $T_{B O G}$ is the gas temperature at the boiler's burners. It is important to highlight that $L H V_{B O G}$ has been assumed constant since the cargo general composition at the moment of loading and unloading was not recorded. A BOG composition model such as the one seen in Dimopoulos and Frangopoulos (2008) is out of the scope of this work. The assumed values used in the previous equations are presented in Table 3.

Table 2. Calorific values assumed per fuel type.

\begin{tabular}{cccc}
\hline & Residual Oil & Distillate Oil & Boil Off Gas \\
\hline Lower Heating Value (MJ/kg) & $40.2^{\mathrm{a}}$ & $42.7^{\mathrm{a}}$ & $48.0^{\mathrm{a}}$ \\
\hline${ }^{\mathrm{a}}$ (International Maritime Organization, 2016) & &
\end{tabular}

Table 3. Additional values assumed for fuels and ship systems.

\begin{tabular}{lllc}
\hline Parameter & Symbol & Unit & Assumed value \\
\hline Fuel specific heat & $C P_{F O}$ & $\mathrm{~kJ} / \mathrm{kg}$ & $1.86^{\mathrm{a}^{*}}$ \\
Fuel temperature at burners & $T_{F O}$ & ${ }^{\circ} \mathrm{C}$ & $110^{\mathrm{a}^{*}}$ \\
Air inlet temperature before boilers & $T A_{i n}$ & ${ }^{\circ} \mathrm{C}$ & $38^{\mathrm{a}}$ \\
Design steam flow to atomizers & $M_{S A}$ & $\mathrm{~kg} / \mathrm{h}$ & $330^{\mathrm{a}}$ \\
Design steam enthalpy to atomizers & $h_{S A}$ & $\mathrm{~kJ} / \mathrm{kg}$ & $3150^{\mathrm{a}}$ \\
Condensate steam enthalpy & $h_{c S}$ & $\mathrm{~kJ} / \mathrm{kg}$ & $2780^{\mathrm{a}}$ \\
Air enthalpy inside boilers & $h_{a l}$ & $\mathrm{~kJ} / \mathrm{kg}$ & $33.60^{\mathrm{a}}$ \\
Air enthalpy before boilers & $h_{a 0}$ & $\mathrm{~kJ} / \mathrm{kg}$ & $9.12^{\mathrm{a}}$ \\
Gas specific heat & $C P_{B G}$ & $\mathrm{~kJ} / \mathrm{kg}$ & $2.20^{\mathrm{a}}$ \\
Gas temperature at burners & $T_{B O G}$ & ${ }^{\circ} \mathrm{C}$ & $30^{\mathrm{a}}$ \\
\hline
\end{tabular}

${ }^{\mathrm{a}}(\mathrm{SNAME}, 1961),{ }^{*}$ values assumed referred to FO.

For a STPS, there are two ways of warming up the air before it enters the boilers: 1) Steam Air Heaters (SAH) which are heat exchangers that use steam to heat the air, and 2) Gas Air Heaters $(\mathrm{GAH})$ where the air is heated up by the exhaust gases. For this reason, Equation 3 is set to zero when the steam vessels use GAH - only four ships are equipped with GAH.

The power input from the diesel generators (DG) is given by the following expression:

$$
\dot{W}_{i n, D G}=\frac{\sum_{i} M_{F O-D G, i} \cdot L H V_{F O, i}}{3600}
$$

Where $\dot{W}_{i n, D G}$ is the DG power input, $M_{F O-D G}$ is the fuel oil consumed by the DG provided by the $\mathrm{CM}$ and $i$ represents the FO type being consumed (i.e. residual or distillate).

The power consumption $\left(\dot{W}_{\text {out }}\right)$ is captured by the following equation:

$$
\dot{W}_{\text {out }}=\dot{W}_{S}+\dot{W}_{T G}+\dot{W}_{D G}+\dot{W}_{F P T}
$$


Where $\dot{W}_{S}, \dot{W}_{T G}$ and $\dot{W}_{D G}$ are the power take-off by the steam turbine, turbo-generators and diesel generators respectively provided by the CM. The turbo-feed pump power consumption $\left(\dot{W}_{T F P}\right)$ is the power required to supply the boilers with water. For this variable, there are no sensors on-board to measure the power consumed, hence a simplified method based on quadratic fits - developed from several steam turbine's heat balances at different loads - was used (Kyma AS, 2018):

$$
\dot{W}_{T F P}=-0.28 \cdot \% M C R_{S}^{2}+57.68 \cdot \% M C R_{S}+990.46
$$

Where $\% M C R_{S}$ refers to steam turbines Maximum Continuous Rating $(M C R)$ percentage. The MCR for the ship's power systems is given by the following general equation:

$$
\% M C R_{i}=\frac{\dot{W}_{\text {out }, i}}{\dot{W}_{M C R, i}} \cdot 100
$$

Where \%MCR is the system's loading, $\dot{W}_{\text {out }, i}$ is the on-board system's delivered power, and $i$ represents the particular ship system. The maximum output power is represented by $\dot{W}_{M C R, i}$ and obtained from IHS (Information Handling Services Markit, 2018).

Steam at lower pressures and temperatures is fed to other auxiliary systems such as deaerators and desuperheater among others (Mrzljak et al., 2018; Mrzljak and Poljak, 2019). These auxiliary systems are outside the scope of this work.

2.5.2. Overall efficiency. The STPS overall efficiency $\left(\eta_{T}\right)$ is described by the following equation:

$$
\eta_{T}=\frac{\dot{W}_{\text {out }}}{\dot{W}_{\text {in, }, b}+\dot{W}_{\text {in,DG }}} \cdot 100
$$

2.5.3. Operating modes. This work uses the Third IMO GHG Study (Smith et al., 2014) operational modes definitions to aggregate general aspects of the ship operation. These operating modes are shown in Table 4 where $v$ is the ship's speed over ground. In this document the term "while at sea" groups together normal cruising, slow steaming and manoeuvring.

Table 4. Logical expressions defining operating modes.

\begin{tabular}{lcl}
\hline Event & Variables Used & Logic Expression \\
\hline Normal cruising & $\dot{W}_{s}$ & $\dot{W}_{s}>65 \% \mathrm{MCR}$ \\
Slow steaming & $\dot{W}_{s}$ & $20<\dot{W}_{s}<65 \% \mathrm{MCR}$ \\
Manoeuvring & $\dot{W}_{s}, v$ & $v>3 \mathrm{kn}$ and $\dot{W}_{s}<=20 \% \mathrm{MCR}$ \\
Anchored & $v$ & $1 \mathrm{kn}<v<3 \mathrm{kn}$ \\
At berth & Shaft RPM, $v$ & $v<1 \mathrm{kn}$ and RPM $<1$ \\
\hline
\end{tabular}

2.5.4. Secondary filtering. Finally, $0.87 \%$ of the observations were eliminated due to $\eta_{T}$ being larger than $80 \%$. In total, $13.59 \%$ of the initial observations were removed through the filtering processes.

\section{RESULTS.}

3.1. Time distribution and Speed Profiles. On average, and only considering while at sea operations, the LNGC sailed 10.9 days under laden conditions (i.e. $46 \%$ of the time), covering an average distance of $3,416 \mathrm{~nm}$, and 12.8 days under ballasted conditions (i.e. $54 \%$ of the time) with an average distance of 3,345 $\mathrm{nm}$. For laden legs, the average speed was observed to be $15.5 \mathrm{kn}$ which gives a ratio of 0.78 between averaged operating speed and design speed, while for ballast, the average speed was $15.4 \mathrm{kn}$ with a ratio of 0.74 (see Figure 2).

From Figure 2, it can be inferred that STPS are being built with a high preference for slowsteaming due to its associated fuel-saving potential. This is highly beneficial for low-efficiency propulsive systems such as the steam turbine (Ekanem Attah and Bucknall, 2015). The average total distance for a single voyage equated to $6,762 \mathrm{~nm}$ with 13.7 voyages per year. 


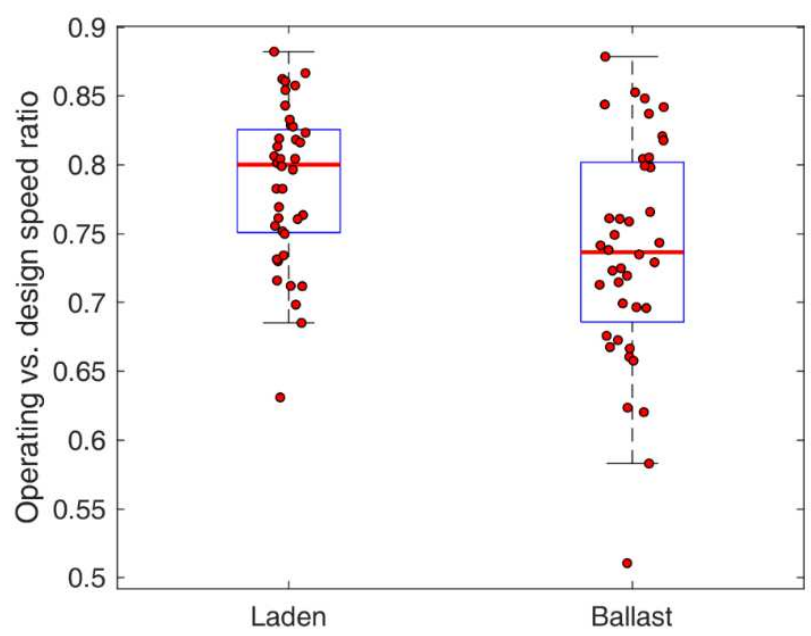

Figure 2. Ratio of average operating speed and design speed under loading conditions.

The addition of operational modes allows for the understanding of the differences between duration and distance for laden and ballast legs (see Figure 3 and Table 5). Activities spent near ports (i.e. anchor, berth and manoeuvring) required more time at ballast conditions (i.e. 19.1\%) than laden (i.e. 8.4\%). One plausible explanation is that during the ballast legs, the temperature in the cargo tanks must be the correct one to receive LNG to minimise thermal stresses while minimising BOG generation (Lu et al., 2016; Shao et al., 2018). This cooling procedure adds time to the ballast leg, as seen in Figure 3, for the berthing time. The time spent while at sea for laden conditions accounted for $39.4 \%$ while the ballast legs represented $40.6 \%$.

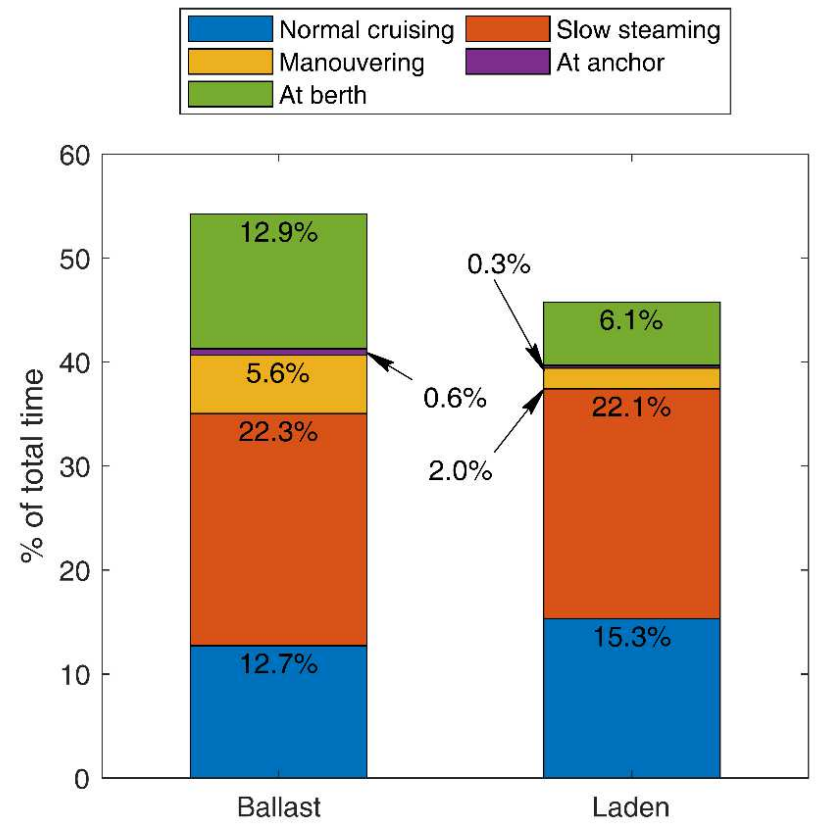

Figure 3. Time distribution for the LNGC sample aggregated by loading condition and events.

The Third IMO GHG study (Smith et al., 2014), gives an average speed while at sea of $14.9 \mathrm{kn}$ for liquefied gas tanker fleet of the same capacity range (i.e. 50,000-199,999 $\mathrm{m}^{3}$ ) for the year 2012, Olmer et al. (2017) showed that the average operational speed between 2013 and 2015 reduced slightly and the Fuel Use Statistic and Emissions (FUSE) report gives an overall speed of $14.4 \mathrm{kn}$ for the year 2016 (UMAS, 2016). The average while at sea speed for 2016 from the $\mathrm{CM}$ dataset $-26,122$ observations - is found at $15.0 \mathrm{kn}$. The difference between steam-powered LNGC and the whole liquefied gas tanker fleet speeds have important implications on the quantification of emissions and fuel consumption on bottom-up approaches since they tend to 
aggregate the whole fleet per ship class ${ }^{2}$ under an average speed and ship/propulsion efficiency. The higher STPS operational speeds coupled with lower propulsive efficiency (Tu et al., 2019) will tend to estimate more $\mathrm{CO}_{2}$ emissions per ship than an $\mathrm{LNGC}$ with an alternative propulsion system (e.g. dual-fuel four-stroke diesel engine).

Table 5. Averaged operational speed for the steam-powered LNGC fleet.

\begin{tabular}{lcc}
\hline \multicolumn{1}{c}{ Voyage leg } & $\begin{array}{c}\text { Average sailing speed (kn) } \\
\text { Ballast }\end{array}$ & \begin{tabular}{c} 
Laden \\
\hline Normal cruising
\end{tabular} \\
Slow steaming & 18.0 & 17.7 \\
Manoeuvring & 14.2 & 14.7 \\
At anchor & 8.4 & 8.2 \\
At berth & 1.9 & 1.9 \\
\hline
\end{tabular}

Figure 4 shows an operational speed preference of between 14.0 and $18.0 \mathrm{kn}$ for both ballast and laden conditions accounting for $47.3 \%$ of the time. Just $3.7 \%$ of the time is spent at speeds equal to or above $18.0 \mathrm{kn}-2.2 \%$ for ballast conditions and $1.4 \%$ laden - while speeds bellow $1.0 \mathrm{kn}$ represented $19.5 \%$ of the total time observed.

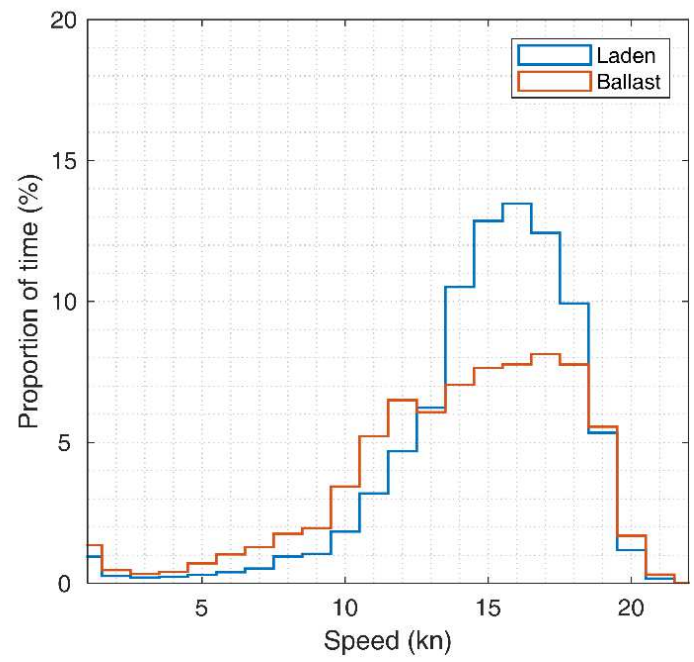

Figure 4. Average speed distribution of the total time observed for the different vessels analysed.

3.2. Fuel consumption and power generation. The fleet consumed $8.989 \times 10^{5} \mathrm{t}$ BOG, $3.294 \times 10^{5}$ t RO and $1.227 \times 10^{4}$ t DO. The most common burning modes are the dual (RO + BOG) and pure BOG mode. Distillate Oil is used in a small number of vessels (i.e. 13 LNGC) and it is seldom burned, normally in conjunction with BOG (see Table 6).

When converting fuel to power, the LNGC boiler average power input $61.4 \mathrm{MW}$ at laden conditions and 50.3 MW for ballast conditions. From Figure 5, it can be seen that the majority of the power was derived from BOG, albeit there is always a share of HFO being burnt. At speeds between 0.0 and $7.0 \mathrm{kn}$, in both conditions, the boiler power output is dominated by the auxiliary systems with BOG making up a larger proportion of the fuel mix. Above $7.0 \mathrm{kn}$, the propulsive power demand guides the upward trend on the boiler power input. The additional boiler power required is sustained by additional BOG consumption up to above $13.0 \mathrm{kn}$ when ballasted and $15.0 \mathrm{kn}$ when laden. Above these speeds, the consumption of RO starts to increase. Under ballast conditions, the power obtained by burning BOG reaches a maximum of 41.9 MW at $19.0 \mathrm{kn}$ to then decline. The boiler is complimented by RO with a maximum power input of $31.0 \mathrm{MW}$ at $20.0 \mathrm{kn}$. For laden conditions, the power production due to BOG consumption reaches its maximum of $62.0 \mathrm{MW}$ at a speed of $20.0 \mathrm{kn}$ while for RO was

\footnotetext{
${ }^{2}$ Smith et al. (2014) grouped LNGC under Liquefied Gas Tanker with $\mathrm{CO}_{2}$ carriers, chemical tanker and Liquefied Petroleum Gas carriers.
} 
17.1 MW at the same speed. Regarding DO, the maximum power obtained was 1.2 $\mathrm{MW}$ for ballast legs and 1.9 MW for laden legs.

Table 6. Power distribution per event and fuel type, and time distribution per fuel combination.

\begin{tabular}{|c|c|c|c|c|c|c|c|c|}
\hline & \multicolumn{3}{|c|}{$\begin{array}{l}\text { Average power } \\
\text { from fuel (MW) }\end{array}$} & \multicolumn{5}{|c|}{$\begin{array}{c}\text { Average time in } \\
\text { fuel mode }(\%)\end{array}$} \\
\hline & $\mathrm{RO}$ & DO & $\mathrm{BOG}$ & RO only & BOG only & $\mathrm{RO}+\mathrm{BOG}$ & $\mathrm{DO}+\mathrm{BOG}$ & $\mathrm{RO}+\mathrm{DO}+\mathrm{BOG}$ \\
\hline At sea & 17.5 & 0.3 & 53.6 & 1.2 & 32.8 & 64.4 & 1.4 & 0.2 \\
\hline Slow steaming & 9.7 & 0.3 & 40.6 & 1.9 & 49.5 & 47.2 & 1.2 & 0.2 \\
\hline Manoeuvring & 8.6 & 0.3 & 22.3 & 4.7 & 44.7 & 47.4 & 2.7 & 0.5 \\
\hline At anchor & 9.9 & 0.8 & 17.7 & 14.9 & 12.6 & 65.5 & 4.6 & 2.4 \\
\hline At berth & 8.8 & 0.9 & 15.9 & 22.8 & 20.4 & 51.0 & 3.1 & 2.7 \\
\hline
\end{tabular}
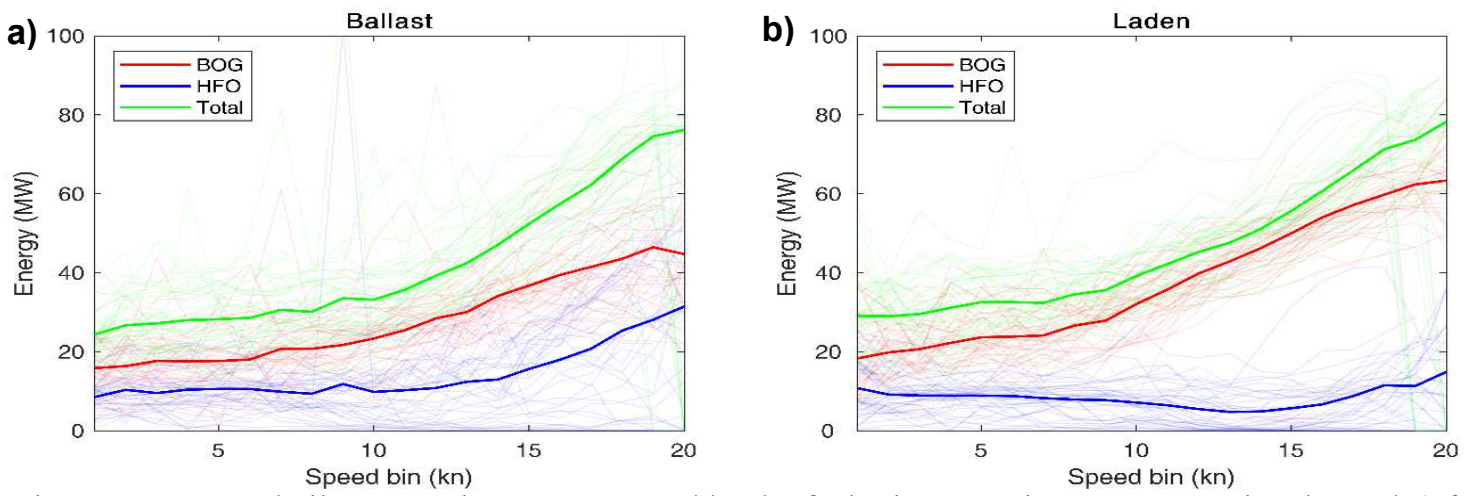

Figure 5. Average boiler power input represented by the fuel mix power input per operational speed a) for ballast legs, and b) for laden legs. Shaded lines represent the fuel mix power input for each ship.

Power generation is relatively similar at berth, anchor and manoeuvring, between 25.0 and 28.0 MW when at ballast and between 33.0 MW and 37.0 MW at laden conditions. In slow steaming mode, the average power consumed is $52.3 \mathrm{MW}$ at ballast and $58.5 \mathrm{MW}$ at laden. However, for normal cruising, the power input is virtually the same at $80.9 \mathrm{MW}$ for ballast and 81.4 MW at laden. This has to do mainly to the higher operational speed at ballast in comparison to laden for this operational mode (see Table 5).

Figure 6 shows that the boiler power input distribution has two peaks between 32.0 and 43.0 MW per hour and between 55.0 and 75.0 MW per hour. The first peak is due to an operational speed between 11.0 and $12.0 \mathrm{kn}$ but as well by the LNGC loading and unloading of its cargo where the speed is $0.0 \mathrm{kn}$. The majority of the observations for this peak occur when the ship is in ballast conditions (i.e. about $64.9 \%$ of the observations). The second peak in Figure 6 has to do mainly with speeds between 15.0 and $16.0 \mathrm{kn}$. In this peak, the majority of the observations happen while the LNGC are in laden conditions (i.e. about 56.7\%).

On regards of DGs, only seven of the 40 ships had sensors installed of which they operated 730 hours, representing $0.9 \%$ of the time for the seven ships or $0.2 \%$ of all observations. Looking only into the seven LNGC with DG sets, the largest average DG power input happens at berth with $2.4 \mathrm{MW}$ (i.e. about $9.0 \%$ of the boiler power input for the same operational mode) for $24.2 \%$ of the ballast time and $13.9 \%$ of the laden time. The lowest DG power input is during slow steaming at $0.8 \mathrm{MW}$ (i.e. about $1.4 \%$ of the boiler power input), covering $39.8 \%$ of the DG operational time during ballast and $47.2 \%$ of the laden time (see Table 7). It can be concluded that the DG sets play a supportive or back-up role on-board LNGC. 


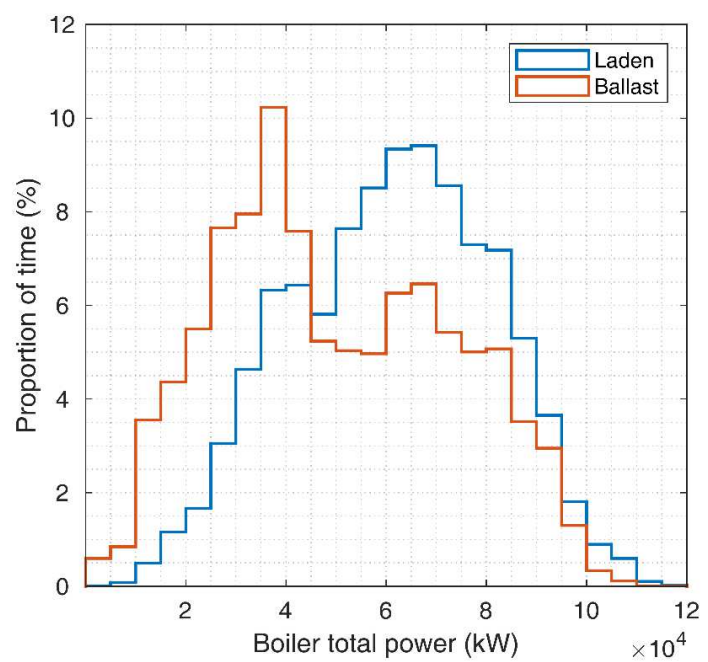

Figure 6. Boiler power input distribution for all data observed, split by loading condition.

Table 7. Proportion of time with DG operation (only considering the ships that had DG sets).

\begin{tabular}{lcc}
\hline \multirow{2}{*}{ Operating Mode } & \multicolumn{2}{c}{ Proportion of time (\%) } \\
\cline { 2 - 3 } & Ballast & Laden \\
\hline Normal cruising & 24.0 & 33.5 \\
Slow steaming & 39.8 & 47.2 \\
Manoeuvring & 10.9 & 4.7 \\
At anchor & 1.1 & 0.7 \\
At berth & 24.2 & 13.9 \\
\hline
\end{tabular}

3.3. Power consumption. The power consumers covered in this work are the propulsion system, evaporators, feed-pumps, turbo-generators (TG) and DG. The maximum power demanded by the LNGC is seen at the $20.0 \mathrm{kn}$ bin with 27.1 MW when the ship is in ballast and $27.8 \mathrm{MW}$ when it is laden, this difference is caused mainly due to the difference in cargo.

Figure 7 shows the power consumption percentage by operational mode. The major power consumer during normal cruising, slow steaming and manoeuvring is the propulsion system, while at anchor and berth is the TG covering the hotel load.

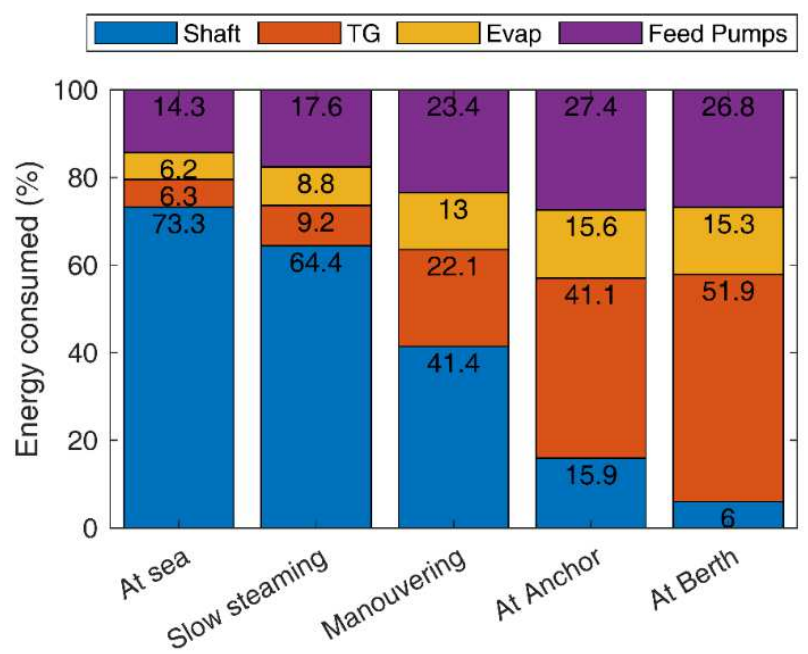

Figure 7. Energy consumers during operation modes.

3.3.1. Shaft power. For all bin speeds, it is seen that the laden condition demanded the highest power mainly due to the loading condition (see Figure 8). The average shaft power for laden conditions was observed to be $12.3 \mathrm{MW}$ while at ballast was 9.1 MW. From Figure 8, it is seen 
that the average shaft power increases in an exponential behaviour as the operational speed increases to then behaving as an asymptote at around $18.0 \mathrm{kn}$. The expected behaviour is that the speed-power curve keeps growing on a cubic relationship (Woud and Stapersma, 2012), but due to a reduced number of observations reaching speeds above $18.0 \mathrm{kn}$ a data artefact is created, causing the asymptote behaviour.

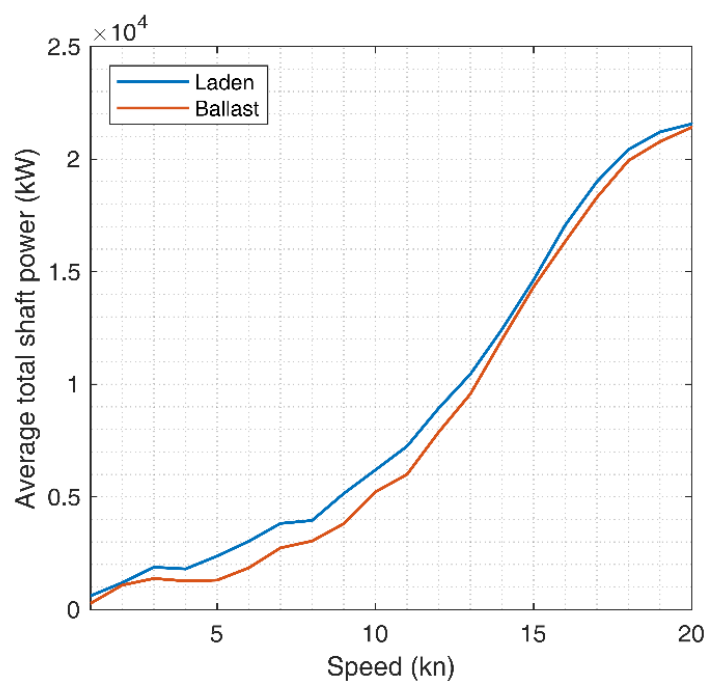

Figure 8. Averaged shaft power at different speed bins for both loading conditions.

Figure 9 shows that for MCR below 30\%, ballast conditions are more common with the largest difference between loading conditions at the 10\% MCR bin which is associated with the ship being at berth. Larger MCR bins tend to be more equally distributed for both loading conditions but they tend to be more common in laden conditions. The most common MCR bins are the $60 \% \mathrm{MCR}$ - with about $12 \%$ of the observations - and the $90 \%$ MCR bin - with about $11 \%$ of the observations. The $60 \% \mathrm{MCR}$ bin is associated with operational speeds between 15.0 and $17.0 \mathrm{kn}$ for both loading conditions, while the $90 \%$ MCR bin has operational speeds for ballast condition between 18.0 and $20.0 \mathrm{kn}$ and for laden conditions between 17.0 and $19.0 \mathrm{kn}$.

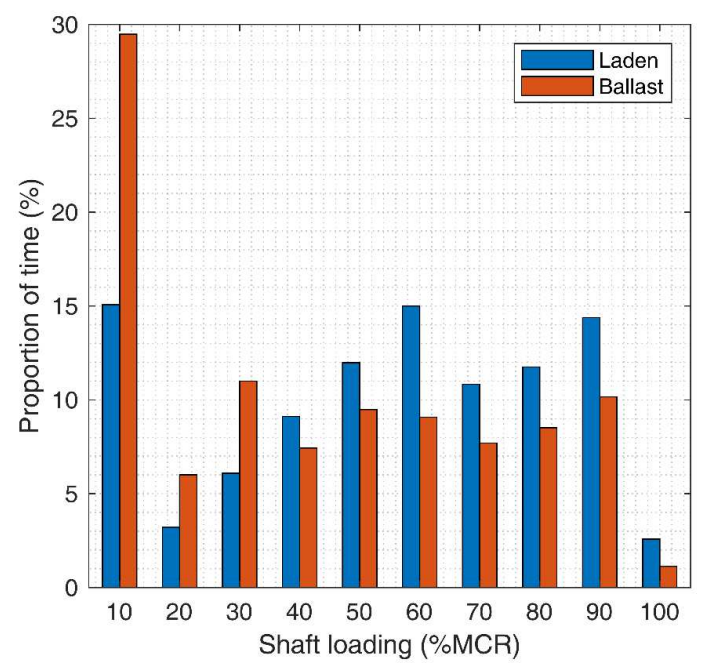

Figure 9. Distribution of the shaft's MCR observations. Each loading condition adds $100 \%$ and bin $10 \%$ MCR represents loadings between 0 and $10 \% \mathrm{MCR}$.

The figure as well shows that the LNGC carriers seldom operate at MCR larger than $90 \%$, associated with speeds above $18.0 \mathrm{kn}$ for both loading conditions. The intersection between different MCR bins but with similar operational speeds could be caused by different cargo 
loading, hull fouling, machinery maintenance and weather conditions which are outside of the scope of this work (Doulgeris et al., 2012; Prpić-Oršić and Faltinsen, 2012; Smith et al., 2014). Table 8 shows that the highest average shaft power is seen for Normal cruising at around $19,600 \mathrm{~kW}$ while the lowest, i.e. $410 \mathrm{~kW}$, is at berth where the speed is zero.

Table 8. Averaged shaft power and MCR for the different operational modes.

\begin{tabular}{lcccc}
\hline \multirow{2}{*}{ Mode } & \multicolumn{2}{c}{ Ballast } & \multicolumn{2}{c}{ Laden } \\
\cline { 2 - 5 } & $\begin{array}{c}\text { Shaft Power } \\
(\mathbf{k W})\end{array}$ & $\begin{array}{c}\text { MCR } \\
\mathbf{( \% )}\end{array}$ & $\begin{array}{c}\text { Shaft Power } \\
\mathbf{( k W )}\end{array}$ & $\begin{array}{c}\text { MCR } \\
(\%)\end{array}$ \\
\hline Normal cruising & 19,600 & 78.7 & 19,738 & 79.6 \\
Slow steaming & 10,205 & 41.3 & 11,373 & 45.7 \\
Manoeuvring & 2,680 & 10.8 & 3,086 & 12.2 \\
At anchor & 528 & 2.1 & 790 & 3.2 \\
At berth & 410 & 1.6 & 478 & 1.9 \\
\hline
\end{tabular}

3.3.2. Auxiliary systems: Electrical generation. The electrical load are normally supplied by two TG. Besides, on the STPS, there are DGs, which are intended to be a backup measure in case TGs fail, any issue occurs in the steam generation, or for use in extended waiting periods without cargo on-board.

The installed power per TG ranges between 2.0 to $3.5 \mathrm{MW}$ with an average of 3.2 MW. The total TG installed power is found between 5.4 MW and 6.9 MW with an average of 6.4 MW. From Table 9, there is a distinct operational preference - around $80 \%$ of the time - for running two TGs for operational modes with low-speed and activities around port which support the unloading of the cargo. During slow steaming and normal cruising, the preferred choice is to use a single TG (i.e. between $59 \%$ and $70 \%$ of the time respectively).

Table 9. Averaged TG usage time, loading and power output for each operational mode. Averaged total power output shows the power delivered to the ship by either a single or both TGs installed.

\begin{tabular}{lccccccc}
\hline & \multicolumn{2}{c}{$\begin{array}{c}\text { Time } \\
(\%)\end{array}$} & & $\begin{array}{c}\text { Auxiliary load } \\
(\% \text { MCR) }\end{array}$ & \multicolumn{2}{c}{$\begin{array}{c}\text { Power output } \\
\text { (MW) }\end{array}$} & $\begin{array}{c}\text { Ave. total power } \\
\text { output (MW) }\end{array}$ \\
\hline $\begin{array}{c}\text { Number of TGS } \\
\text { operational }\end{array}$ & 1 & 2 & 1 & 2 & 1 & 2 & \\
\hline Normal cruising & 69.8 & 30.1 & 48.2 & 25.6 & 1.63 & 1.74 & 1.62 \\
Slow steaming & 59.2 & 40.6 & 44.6 & 23.4 & 1.50 & 1.60 & 1.54 \\
Manoeuvring & 32.3 & 67.4 & 41.4 & 23.4 & 1.38 & 1.60 & 1.50 \\
At anchor & 16.5 & 82.8 & 39.9 & 27.5 & 1.21 & 1.88 & 1.82 \\
At berth & 22.8 & 76.7 & 41.5 & 34.0 & 1.27 & 2.33 & 1.96 \\
\hline
\end{tabular}

Table 9 as well shows that as a single TG reaches a load between 40.0 and 50.0\% MCR when a second TG engages. The loading window when both TGs are operating becomes between 20.0 and $35.0 \%$ MCR where, on average, the power output for both TGs are within $3.0 \%$ of each other. Looking at the load distribution for both TGs in Figure 11 shows that around a third of the time the TGs were idle but as well that there are another two distinct operational time peaks. The first peak is seen between a load of 15.0 and 25.0\% MCR which represents the time that both TGs cover the auxiliary load simultaneously. The second peak, between $35.0 \%$ and $45.0 \% \mathrm{MCR}$, shows the time that a single $\mathrm{TG}$ was operating.

From a thermodynamical point of view, the most optimal operational window for TGs starts above 50.0\% MCR (Mrzljak et al., 2018). However, the data shows that the majority of the time (i.e. about 61\%) the TGs are operated below 55.0\% MCR. This shows that STPS have excess installed auxiliary power allowing for few TGs to respond better to a wide range of electrical loads. Running at lower loads reduces the vibrations experienced by the TGs which could allow for longer periods between maintenance. Further, getting steam turbines running take considerable time (Bachmann et al., 1999; Banaszkiewicz, 2014), which in case a TG suddenly fail, it could compromise the safety and operation of the LNGC, so operating two TGs simultaneously allows for more robust operation. All these aspects could outweigh the benefit of operating the TGs at higher efficiency (Adamkiewicza and Drzewienieckij, 2013). 
The average installed power per DG was $1,750 \mathrm{~kW}$. The DGs operate $87.4 \%$ time alongside the TGs and $58 \%$ of the DG observed operational time happens using a single DG. Contrary to the TGs, when both DGs are operating their load difference is around $23.2 \%$.

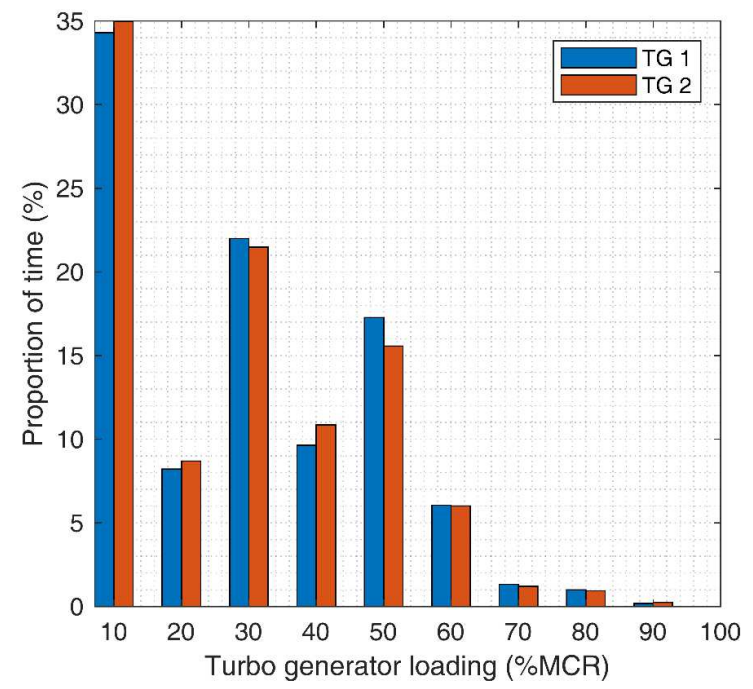

Figure 10. Load distribution for both TGs on board the LNGC.

3.3.3. Auxiliary systems. Turbo-feed pump. The turbo-feed pump (TFP) moves water/steam inside the boiler system, normally there are two to three pumps per boiler on board. Due to the nature of Equation (9), there is a direct relationship between the total TFP power consumption and shaft power. Figure 11 shows that when the ship is idle, the TFP power output is on average $1,040 \mathrm{~kW}$. As the LNGC increases its speed, and hence its shaft power output, the TFP demand increases reaching a maximum of $3,820 \mathrm{~kW}$ at a bin speed of $20.0 \mathrm{kn}$.

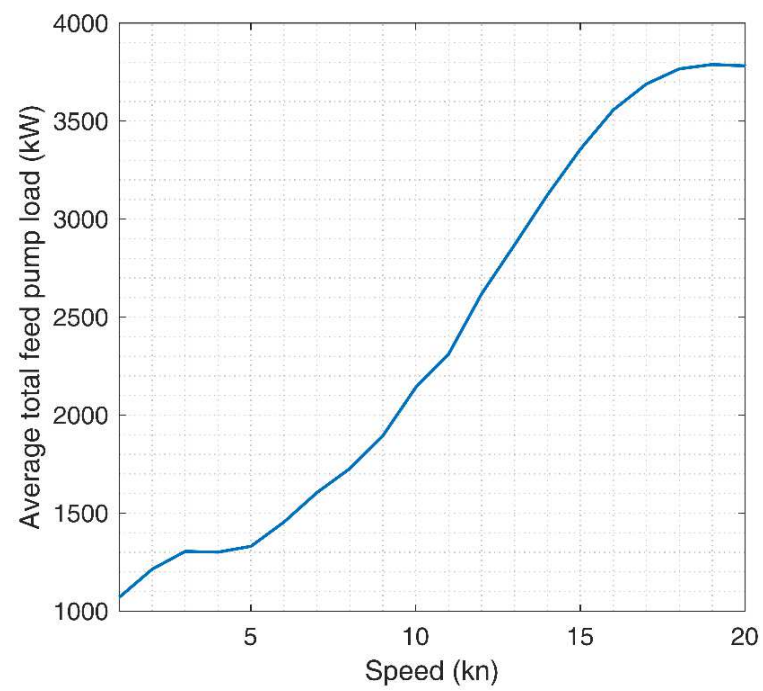

Figure 11. Averaged power output from the TFP at different operational bin speeds.

3.3.4. Steam dump. The LNGC with steam plants have a dedicated steam line known as dump line, which acts as a safety measure to evacuate the surplus steam generated by the main boilers (Mrzljak et al., 2018). Figure 12 shows that the majority of the steam being dump while the ship is in laden condition occurs between 6.0 and $12.0 \mathrm{kn}$ - lower loads - with an averaged steam dump of $3,340 \mathrm{~kg} / \mathrm{h}$. The operational mode with the highest steam dump at laden condition is manoeuvring with an average of $3,340 \mathrm{~kg} / \mathrm{h}$, followed by at anchor with $1,260 \mathrm{~kg} / \mathrm{h}$ (see Table 10). At higher speed bins and laden conditions, steam dump is reduced since at higher speeds the BOG is consumed in its totality. Mrzljak and Poljak (2019) present a similar finding when measuring the steam flows on-board an 84,812 dwt LNGC. This behaviour is expected because during laden conditions, the tanks are topped with the LNG cargo and due 
heat leak into the tanks forms BOG at a rate of about $0.10 \%$ to $0.15 \%$ of the cargo volume per day (Mokhatab, 2014). The BOG causes an increment in the cargo tank internal pressure, which for safety reasons must be kept within certain limits. Therefore, the internal tank pressure is relieved by sending BOG excess to the main boilers, where is burned and steam is generated. A lower, but still considerable amount of steam dump, is seen between 1.0 and $5.0 \mathrm{kn}$ (i.e. anchoring and manoeuvring) where the ship is most likely waiting for its spot at the LNG terminal near it or, depending on the terminal's safety protocols (e.g. against pirates), in deep waters. Under these modes, the power demanded is low and hence the need to dump steam.

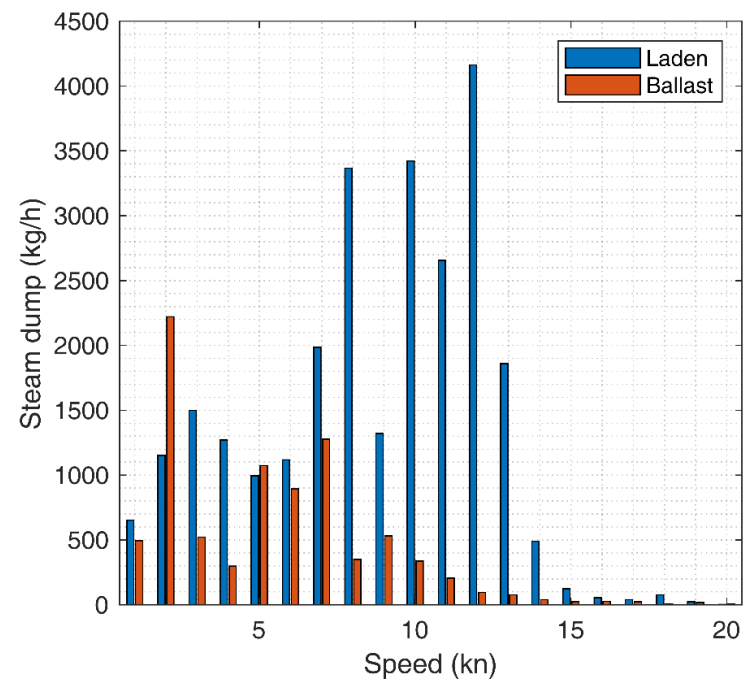

Figure 12. Averaged steam dump per operational speed bin and loading condition.

During ballast, the tanks are only carrying a small amount of LNG (heel) which is optimised to keep the tanks cold while the BOG generated is used as fuel, reducing considerably the amount of excess steam being dumped (as seen in Table 10). Under this condition, the largest averaged steam dump occurs at a speed of $1.0 \mathrm{kn}$ with $2,280 \mathrm{~kg} / \mathrm{h}$. At this speed the ship is at anchor, probably waiting for port or the platform to be available, implying that if there is a bad voyage planning, the LNGC will need to wait for long periods requiring to dump steam and impacting the general voyage efficiency. The maximum steam dump during ballast legs and while navigating occurs when the LNGC is slow steaming at $7.0 \mathrm{kn}$ with a dump of $1,683 \mathrm{~kg} / \mathrm{h}$. At berth, due to vapour displacement and heat leakage (Huang et al., 2007) steam dump is about $540 \mathrm{~kg} / \mathrm{h}$.

Table 10. Averaged steam dump at the different operational modes.

\begin{tabular}{lcc}
\hline \multirow{2}{*}{ Operating Mode } & \multicolumn{2}{c}{ Total steam dump } \\
& \multicolumn{2}{c}{ (kg/h) } \\
\cline { 2 - 3 } & Ballast & Laden \\
\hline Normal cruising & 9.6 & 12.7 \\
Slow steaming & 57.3 & 739.1 \\
Manoeuvring & 520.5 & 3341.1 \\
At anchor & 1683.3 & 1261.1 \\
At berth & 539.8 & 701.7 \\
\hline
\end{tabular}

3.4. Thermal efficiency. The STPS total efficiency is seen increasing as the ship operational speed does from about $13.9 \%$ at laden and $14.3 \%$ at ballast when idle to a maximum of $37.7 \%$ for laden and $37.2 \%$ for ballast when navigating around $20.0 \mathrm{kn}$ (see Figure 13). Sinha and Nik (2012) give a similar maximum efficiency for a $157,000 \mathrm{~m}^{3} \mathrm{LNGC}$ when fully loaded. At lower speed bins the ship efficiency is at its lowest caused by a low demand by the consumers (e.g. propulsion), extra steam being dumped (Figure 12) and not operating at their optimal efficiency window (Mrzljak et al., 2017; Mrzljak and Poljak, 2019). As the operational speed increases 
so does the overall efficiency in both loading conditions, thanks to the individual systems operating at higher thermal efficiencies.

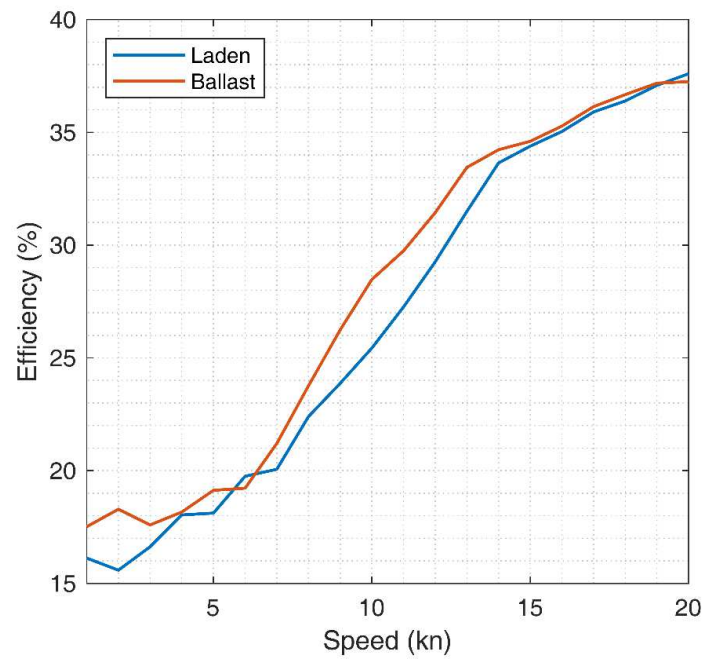

Figure 13. LNGC operational efficiency per operational bin size per laden and conditions.

Another point to highlight is the influence of the steam dump on efficiency represented in Figure 14 for a single laden voyage. It is seen that the efficiency drops considerably, from about $34.0 \%$ to well below $10.0 \%$, as steam is being dumped. As shown in Figure 12, steam dump happens predominately at speeds lower than $14.0 \mathrm{kn}$, at which the averaged efficiency for both loading conditions reaches about 30.5\%. During ballast voyages, LNGC performed, on average, three percentual points above laden voyages between bin speeds 6.0 and $13.0 \mathrm{kn}$ where the largest amount of steam is being dumped at laden conditions. Where the difference in steam dump between loading conditions is reduced and under similar operating speed, the LNGC efficiencies become relatively similar - an averaged difference of 0.4 percentual points.

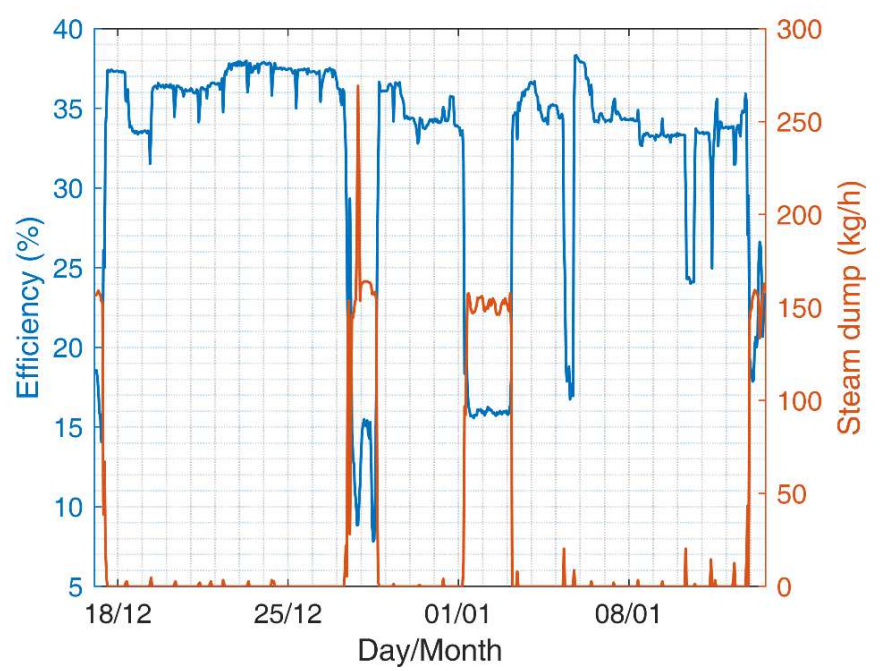

Figure 14. Typical LNGC voyage efficiency against its steam dump.

3.5. Data Heterogeneity and uncertainty. Due to the large dataset in this work results were presented in an aggregated form which covers the heterogeneity of the data being recorded by the CM. Figures 6 and 14 illustrate this variation which is expected as it is seen in all similar studies even those comparing sister vessels on similar operating profiles (Christensen et al., 2018). While some of the fluctuations are caused by the recording uncertainty of the CM's sensors (Table 1), there are important factors which could not be accounted for due to confidentiality restrictions or lack of data collection. These missing data points can be characterised as vessel-related (hull, propeller and machinery condition; hydrodynamic 
retrofits or energy efficiency interventions), operational (maintenance routine, fuel quality, cargo utilisation, weather, trade routes) and commercial (chartering regimes and freight rates) factors.

All of these could contribute to part of heterogeneity and not enough information to determine the degree of the effect on the outcome observed.

4. CONCLUSIONS. This work analyses the high-frequency in-service monitoring data of 40 steam-powered LNGC, representing about $16.5 \%$ fleet. The paper provides clarity into the energy consumption on STPS. It provides clarity on LNG transport by STPS ships, without the use of general assumptions for critical parameters thanks to the use of high-frequency data. The evidence of this work offers a solid basis for future modelling and simulation studies and provides a precise and in-depth operational profile for LNGC capturing important complexities relevant to their operational efficiency and $\mathrm{CO}_{2}$ inventories.

It was found that, on average, STPS spend $56 \%$ of its time in ballast conditions with an average operational speed $26 \%$ lower of the fleet design speed. For laden conditions, the average speed was $22 \%$ lower than at the design point, showing the preference for slow steaming. In contrast, some bottom-up studies tend to assume an even lower operational speed impacting the quantification of $\mathrm{CO}_{2}$ inventories.

For all operational speeds and loading conditions, LNGC mainly consumed BOG and RO. In comparison, DO was consumed in small quantities by DG sets. The main power consumer, at high operational speed bins, was the shaft with $73.0 \%$ of the power consumed. While at low speeds, TG and TFP represented $84.0 \%$. It was shown that TGs operated below their thermal efficiency peak due to operational flexibility, maintenance and safety.

The STPS show the largest efficiency at high speeds at $37.0 \%$. However, dumping steam reduces efficiency, with a particular case where it goes from $34.0 \%$ to $10.0 \%$. Steam dump occurs mainly while the ship is in laden conditions between 6.0 and $12.0 \mathrm{kn}$ to relieve the cargo tank pressure while power demand is low. As well, steam dump is seen at ballast conditions when the STPS is anchored, waiting for the port and platform to become available.

\section{REFERENCES}

Adamkiewicza, A., Drzewienieckij, J., 2013. Service and maintenance of marine steam turbogenerators with the assistance of vibration diagnostics. Polish Marit. Res. 20, 31-38. https://doi.org/https://doi.org/10.2478/pomr-2013-0004 Open access

Afon, Y., Ervin, D., 2012. An Assessment of Air Emissions from Liquefied Natural Gas Ships Using Different Power Systems and Different Fuels. J. Air Waste Manage. Assoc. 58, 404-411. https://doi.org/http://dx.doi.org/10.3155/1047-3289.58.3.404

Aguilera, R.F., 2014. The role of natural gas in a low carbon Asia Pacific. Appl. Energy 113, 1795-1800. https://doi.org/10.1016/j.apenergy.2013.07.048

Bachmann, R., Nielsen, H., Warner, J., Kehlhofer, R., 1999. Combined-Cycle Gas \& Steam Turbine Power Plants, 2nd ed. PennWell Publishing Company, Tulsa.

Banaszkiewicz, M., 2014. Steam turbines start-ups. Trans. Inst. Fluid-Flow Mach. 169-198.

Calderón, M., Illing, D., Veiga, J., 2016. Facilities for Bunkering of Liquefied Natural Gas in Ports. Transp. Res. Procedia 14, 2431-2440. https://doi.org/10.1016/j.trpro.2016.05.288

Chang, D., Rhee, T., Nam, K., Chang, K., Lee, D., Jeong, S., 2008. A study on availability and safety of new propulsion systems for LNG carriers. Reliab. Eng. Syst. Saf. 93, 1877-1885. https://doi.org/10.1016/j.ress.2008.03.013

Christensen, L.B.R., Thomas, G., Calleya, J., Nielsen, U.D., 2018. The Effect of Operational Factors on Container Ship Fuel Performance. Proc. Full Scale Sh. Perform. 2018.

Cipollini, F., Oneto, L., Coraddu, A., Murphy, A.J., Anguita, D., 2018. Condition-Based Maintenance of Naval Propulsion Systems with supervised Data Analysis. Ocean Eng. https://doi.org/10.1016/j.oceaneng.2017.12.002

Coello, J., Williams, I., Hudson, D.A., Kemp, S., 2015. An AIS-based approach to calculate atmospheric 
emissions from the UK fishing fleet. Atmos. Environ. https://doi.org/10.1016/j.atmosenv.2015.05.011

Coraddu, A., Oneto, L., Baldi, F., Anguita, D., 2017. Vessels fuel consumption forecast and trim optimisation: A data analytics perspective. Ocean Eng. 130, 351-370. https://doi.org/10.1016/J.OCEANENG.2016.11.058

Dalheim, Ø. Ø. and Steen, S. (2020) Preparation of in-service measurement data for ship operation and performance analysis, Ocean Eng. 212, p.1-17. doi: https://doi.org/10.1016/j.oceaneng.2020.107730

Datum Electronics Limited, 2018. Commercial Marine Shaft Power Meter Handbook.

Dimopoulos, G.G., Frangopoulos, C.A., 2008. A Dynamic Model for Liquefied Natural Gas Evaporation During Marine Transportation. Int. J. Thermodyn. 11, 123-131. https://doi.org/10.5541/IJOT.1034000220

Dobrota, Đ., Lalić, B., Komar, I., 2013. Problem of Boil - off in LNG Supply Chain. Trans. Marit. Sci. 2, 91-100. https://doi.org/10.7225/toms.v02.n02.001

Dohan, K., 2017. Ocean surface currents from satellite data. J. Geophys. Res. Ocean. 122, 2647-2651. https://doi.org/10.1002/2017JC012961

Doulgeris, G., Korakianitis, T., Pilidis, P., Tsoudis, E., 2012. Techno-economic and environmental risk analysis for advanced marine propulsion systems. Appl. Energy 99, 1-12. https://doi.org/10.1016/j.apenergy.2012.04.026

Economides, M.J., Wood, D.A., 2009. The state of natural gas. J. Nat. Gas Sci. Eng. 1, 1-13. https://doi.org/10.1016/j.jngse.2009.03.005

Ekanem Attah, E., Bucknall, R., 2015. An analysis of the energy efficiency of LNG ships powering options using the EEDI. Ocean Eng. 110, 62-74. https://doi.org/10.1016/j.oceaneng.2015.09.040

Fernández, I.A., Gómez, M.R., Gómez, J.R., Insua, Á.B., 2017. Review of propulsion systems on LNG carriers. Renew. Sustain. Energy Rev. 67, 1395-1411. https://doi.org/10.1016/J.RSER.2016.09.095

Gonzalez, C., Lara Arango, D., 2019. Techniques for the Automated Detection of Anomalies and Assessment of Quality in High-Frequency Data Collection Systems, in: Volker Bertram (Ed.), 4th Hull Performance \& Insight Conference. Gubbio, pp. 143-152.

Huang, S., Hartono, J., Shah, P., 2007. Bog Recovery From Long Jetties. Int. Conf. Exhib. Liq. Nat. Gas 2007 1-15.

Hunsucker, J.T., Przelomski, D., Bashkoff, A., Dixon, J., 2018. Uncertainty Analysis of Methods Used to Measure Ship Fuel Oil Consumption.

Information Handling Services Markit, 2020. IHS Maritime World Register of Ships [WWW Document]. Marit. Trade Shipp. Intell. URL https://ihsmarkit.com/products/maritime-world-ship-register.html (accessed 3.9.20).

Information Handling Services Markit, 2018. IHS Maritime World Register of Ships [WWW Document]. Marit. Trade Shipp. Intell. URL https://ihsmarkit.com/products/maritime-world-ship-register.html (accessed 10.10.18).

International Energy Agency, 2018. Security. IEA - Glob. Gas Secur. 2018102.

International Gas Union, 2019. 2019 World LNG Report. Barcelona.

International Gas Union, 2018. 2018 World LNG Report. Barcelona.

International Maritime Organization, 2016. Resolution MEPC.281(70): Amendments to The 2014 Guidelines on The Method of Calculation of The Attained Energy Efficiency Design Index (EEDI) for New Ships (Resolution MEPC.245(66), As Amended By Resolution Mepc.263(68)). Annex 9.

International Organization for Standardization, 2016. ISO 19030 Ships And Marine Technology Measurement Of Changes In Hull And Propeller Performance - Part 1: General Principles.

Jalkanen, J.P., Johansson, L., Kukkonen, J., 2016. A comprehensive inventory of ship traffic exhaust emissions in the European sea areas in 2011. Atmos. Chem. Phys. https://doi.org/10.5194/acp-16-71$\underline{2016}$

Kano, T., Namie, S., 2014. A study on estimation methodology of GHG emission from vessels by using energy efficiency index and time series monitoring data, in: Ehlers, S., Asbjornslett, B.E., Rodseth, O.J., Berg, T.E. (Eds.), Maritime-Port Technology and Development. CRC Press, London, pp. 35-41. https://doi.org/10.1201/b17517-6

Krikkis, R.N., 2018. A thermodynamic and heat transfer model for LNG ageing during ship transportation. Towards an efficient boil-off gas management. Cryogenics (Guildf). 92, 76-83. https://doi.org/10.1016/j.cryogenics.2018.04.007

Kyma AS, 2018. Internal Communications. 
Lin, Y., Yu, Y., Guan, G., 2014. Research on energy efficiency design index for sea-going LNG carriers. J. Mar. Sci. Appl. 13, 430-436. https://doi.org/10.1007/s11804-014-1282-6

Lu, J., Xu, S., Deng, J., Wu, W., Wu, H., Yang, Z., 2016. Numerical prediction of temperature field for cargo containment system (CCS) of LNG carriers during pre-cooling operations. J. Nat. Gas Sci. Eng. 29, 382-391. https://doi.org/10.1016/J.JNGSE.2016.01.009

Merien-Paul, R.H., Enshaei, H., Jayasinghe, S.G., 2018. In-situ data vs. bottom-up approaches in estimations of marine fuel consumptions and emissions. Transp. Res. Part D Transp. Environ. 62, 619-632. https://doi.org/10.1016/j.trd.2018.04.014

Mokhatab, S., 2014. LNG Fundamentals, in: Handbook of Liquefied Natural Gas. Gulf Professional Publishing, Amsterdam, pp. 1-106. https://doi.org/10.1016/B978-0-12-404585-9.00001-5

Moreno-Gutiérrez, J., Pájaro-Velázquez, E., Amado-Sánchez, Y., Rodríguez-Moreno, R., CalderayCayetano, F., Durán-Grados, V., 2019. Comparative analysis between different methods for calculating on-board ship's emissions and energy consumption based on operational data. Sci. Total Environ. 650, 575-584. https://doi.org/10.1016/j.scitotenv.2018.09.045

Mrzljak, V., Poljak, I., 2019. Energy Analysis of Main Propulsion Steam Turbine from Conventional LNG Carrier at Three Different Loads. Naše more 66, 10-18. https://doi.org/10.17818/nm/2019/1.2

Mrzljak, V., Poljak, I., Medica-Viola, V., 2017. Dual fuel consumption and efficiency of marine steam generators for the propulsion of LNG carrier. Appl. Therm. Eng. 119, 331-346. https://doi.org/10.1016/J.APPLTHERMALENG.2017.03.078

Mrzljak, V., Prpić-oršić, J., Senčić, T., 2018. Change in steam generators main and auxiliary energy flow streams during Change in Steam Generators Main and Auxiliary Energy Flow Streams During the Load Increase of LNG Carrier Steam Propulsion System.

Nunes, R.A.O., Alvim-Ferraz, M.C.M., Martins, F.G., Sousa, S.I.V., 2017. The activity-based methodology to assess ship emissions - A review. Environ. Pollut. 231, 87-103. https://doi.org/10.1016/J.ENVPOL.2017.07.099

Olmer, N., Comer, B., Roy, B., Mao, X., Rutherford, D., 2017. Greenhouse Gas Emissions From Global Shipping, 2013-2015. Int. Counc. Clean Transp. 2013-2015.

Petersen, J.P., Jacobsen, D.J., Winther, O., 2012. Statistical modelling for ship propulsion efficiency. J. Mar. Sci. Technol. 17, 30-39. https://doi.org/10.1007/s00773-011-0151-0

Prpić-Oršić, J., Faltinsen, O.M., 2012. Estimation of ship speed loss and associated CO2 emissions in a seaway. Ocean Eng. 44, 1-10. https://doi.org/10.1016/j.oceaneng.2012.01.028

Shao, Y., Lee, Y.-H., Kim, Y.-T., Kang, H.-K., 2018. Parametric Investigation of BOG Generation for Shipto-Ship LNG Bunkering. J. Korean Soc. Mar. Environ. Saf. 24, 352-359. https://doi.org/10.7837/kosomes.2018.24.3.352

Shaton, K., Hervik, A., Hjelle, H.M., 2019. The Environmental Footprint of Natural Gas Transportation: LNG vs. Pipeline. Econ. Energy Environ. Policy 8, 1-22. https://doi.org/10.5547/2160-5890.8.2.ksha

Sinha, R.P., Nik, W.M.N.W., 2012. Investigation of propulsion system for large LNG ships, in: IOP Conference Series: Materials Science and Engineering. pp. 1-16. https://doi.org/10.1088/1757899X/36/1/012004

Smith, T.W.., Raucci, C., Haji Hosseinloo, S., Rojon, I., Calleya, J., Suarez de la Fuente, S., Wu, P., Palmer, K., 2016. CO2 Emissions from International Shipping: Possible reduction targets and their associated pathways. London.

Smith, T.W.P., Jalkanen, J.P., Anderson, B.A., Corbett, J.J., Faber, J., Hanayama, S.., O’Keeffe, E.., Parker, S.., Johansson, L.., Aldous, L.., Raucci, C.., Traut, M.., Ettinger, S.., Nelissen, D.., Lee, D.S.., Ng, S.., Agrawal, A.., Winebrake, J., J.; Hoen, M.., Chesworth, S.., Pandey, A., 2014. Third IMO GHG Study 2014. London.

SNAME, 1961. Recommended Practices for Preparing Marine Steam Power Plant Heat Balances.

Soner, O., Akyuz, E., Celik, M., 2018. Use of tree based methods in ship performance monitoring under operating conditions. Ocean Eng. 166, 302-310. https://doi.org/10.1016/j.oceaneng.2018.07.061

Tu, H., Hongjun, F., Lei, W., Guoqiang, Z., 2019. Options and Evaluations on Propulsion Systems of LNG Carriers, in: Propulsion Systems. IntechOpen, pp. 1-20. https://doi.org/10.5772/intechopen.82154

UMAS, 2016. FUSE [WWW Document]. Products. URL https://u-mas.co.uk/Products/fuse (accessed 7.1.19).

UNCTAD, 2018. Review of Maritime Transport 2018. Geneva.

Varahrami, V., Haghighat, M.S., 2018. The assessment of liquefied natural gas (LNG) demand reversibility 
in selected OECD countries. Energy Reports 4, 370-375. https://doi.org/10.1016/j.egyr.2018.05.006

Wang, K., Yan, X., Yuan, Y., Jiang, X., Lodewijks, G., Negenborn, R.R., 2017. Study on route division for ship energy efficiency optimization based on big environment data. 2017 4th Int. Conf. Transp. Inf. Safety, ICTIS 2017 - Proc. 111-116. https://doi.org/10.1109/ICTIS.2017.8047752

Woud, H.K., Stapersma, D., 2012. Design of Propulsion and Electric Power Generation Systems, 1st ed. IMarEST, London.

Yu, W., Zhou, P., Wang, H., 2018. Evaluation on the energy efficiency and emissions reduction of a shortroute hybrid sightseeing ship. Ocean Eng. 162, 34-42. https://doi.org/10.1016/j.oceaneng.2018.05.016

Zhang, H.Y., Xi, W.W., Ji, Q., Zhang, Q., 2018. Exploring the driving factors of global LNG trade flows using gravity modelling. J. Clean. Prod. 172, 508-515. https://doi.org/10.1016/j.jclepro.2017.10.244

Zheng, H., Huang, Y., Ye, Y., 1999. New level sensor system for ship stability analysis and monitor. IEEE Trans. Instrum. Meas. 48, 1014-1017. https://doi.org/10.1109/19.816106 